\title{
Formal financial institutions financing of immigrant small and medium enterprises in South Africa
}

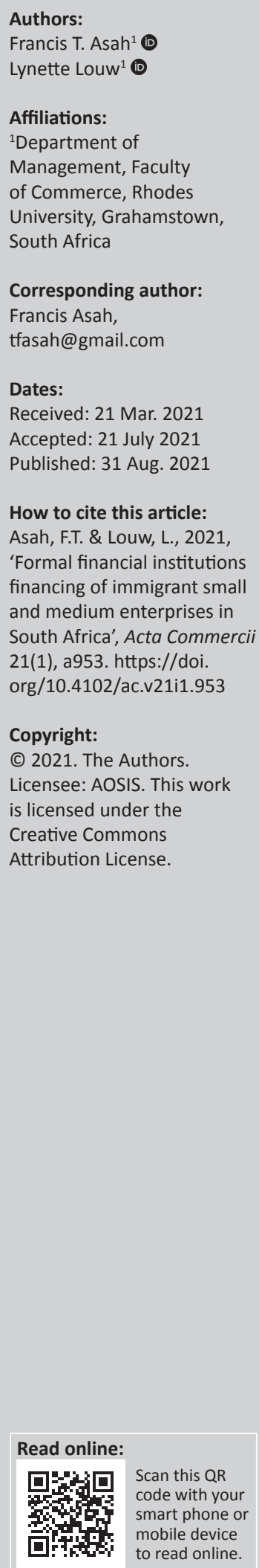

Orientation: Small and medium enterprises (SMEs) owned by immigrants in developing economies, such as South Africa, tend to trust formal financial institutions (FFIs) for financial support.

Research purpose: Even though immigrant SMEs create opportunities that have important implications for the South African economy; less than $5 \%$ of them can access credit from FFIs. This study, therefore, explores the accessibility of credit from FFIs to immigrant SMEs from a supply-side perspective.

Motivation for the study: Research studies on improving financing from FFIs to immigrant SMEs will help to boost the survival of immigrant SMEs and promote economic development in South Africa.

Research design, approach and method: This qualitative research design used an interpretivistic research paradigm to achieve the research objectives. Data were collected from 16 purposively selected participants and analysed using the five-step process of content analysis outlined by Terre Blanche, Durrheim and Kelly.

Main findings: The findings revealed that FFIs are uninterested and biased against considering financing immigrant SMEs and tend to charge them higher interest rates. Collateral, equity contribution and the possession of a South African permanent resident permit with a South African ID are the most important requirements that impact the willingness of FFIs to finance immigrant SMEs.

Practical/managerial implications: Implications for the financial institutions in policy development were provided.

Contribution/value-add: This research study highlights the requirements and the challenges faced by immigrant SMEs in accessing credit from FFIs. The use of qualitative research design further contributed to the literature on FFIs financing of immigrant SMEs.

Keywords: formal financial institutions; supply-side; credit; immigrant; SME.

\section{Introduction}

Research studies on immigrant small and medium enterprises (SMEs) have gained much momentum in recent times. Immigrant SMEs in the contemporary post-modern era have a significant value because of the innovations they create (Jenkins \& McKelvie 2016:176), the wealth they produce and the additional employment they create (Acs et al. 2018:503). Immigrant SMEs create jobs through new business ventures, which, in turn, contribute to wealth creation in every nation (World Bank 2019).

According to the report by the Centre for Entrepreneurs and DueDil (2014) on entrepreneurship in the United Kingdom (UK), there has been a very significant contribution of immigrant SMEs in developed economies towards economic growth over the past few decades. The report suggests that immigrants were responsible for starting $60 \%$ of all the top technology companies in the United States of America (USA). The Organisation of Economic Cooperation and Development (OECD) in its 2017 report indicates that immigrant SMEs account for about 14.5\% of the total employment in the USA (OECD 2017). Meanwhile, the Centre for Entrepreneurs and DueDil (2014) report states that immigrants employing about $14 \%$ of the total labour force own about $20 \%$ of all businesses in the UK. In addition, the European Commission SMEs Performance Review (2013) highlighted that immigrant SMEs contribute about $11 \%$ of all business revenue in the UK. 
In South Africa, there has been a positive change in the government's attitude towards entrepreneurship since the advent of the economic reform programmes in 1996. Entrepreneurship has been identified by the South African government as a priority area for increasing jobs to resolve the high unemployment rate currently estimated at $29.6 \%$ (Statistics South Africa 2020). The World Bank (2019) maintained that one of the best ways to address the challenge of high unemployment in developing countries (such as South Africa) is to leverage the employment creation potential of SMEs and promote their development.

Immigrant SMEs create opportunities that have important implications for the South African economy. These are the most important source of innovation as they introduce new products and develop new technologies (Furawo \& Scheepers 2018:34). They also bring competitive pressure on local SMEs and are more flexible than local businesses (Jenkins \& McKelvie 2016:176). The World Bank (2019) reported that immigrant SMEs can help South Africa to meet its developmental challenges of poverty, unemployment and income inequality as countries with favourable immigrant entrepreneurship legislation have a stronger and better economy compared with those with rigorous immigrant entrepreneurship legislation. This is because immigrant entrepreneurship competes directly withlocalentrepreneurship for market share (World Bank 2019).

Despite the noted importance of immigrant SMEs, these 'unsung heroes' face formidable challenges in any host country (Andersson \& Waldenstrom 2017:723). Of all the challenges, the contemporary literature reveals that the nonavailability of formal sector financing and a lack of access to credit from formal financial institutions (FFIs) are the most important constraints to the development of SMEs (OECD 2017; Turyakira 2018:3; World Bank 2019). Additionally, international organisations (Global Entrepreneurship Monitor [GEM] 2020; OECD 2017; World Bank 2019) highlight that less than $20 \%$ of immigrant SMEs in developing countries have access to formal sector finance. Consistent with the findings of international organisations, the Small Enterprise Development Agency (SEDA) maintains that the majority of credit applications (about $80 \%$ ) by immigrant SMEs to FFIs are rejected in South Africa (SEDA 2017). Given that the majority of immigrant SME owners raise their start-up and running capital from personal or family savings, which are often inadequate for growth and competitiveness, immigrant SME owners consequently rely on financial support from FFIs (Akinboade 2015:184; Fatoki 2014:186; Herrington \& Kew 2014).

A research study by Fatoki (2014:185) revealed that less than $5 \%$ of immigrant entrepreneurs obtain credit from commercial banks in South Africa. Consistent with the findings of Fatoki (2014), Radipere and Dhliwayo (2014) and Tengeh and Nkem (2017) inadequate financing of immigrant SMEs is rooted in supply-side requirements (i.e. requirements known only by credit providers such as FFIs). Additionally, Andersson and
Waldenstrom (2017:723) reiterated that FFIs are uninterested in financing immigrant SMEs in developing countries, such as South Africa, and that the entire financing system is biased against financing immigrant SMEs. This phenomenon is termed the discrimination hypothesis. Given the vital contributions of immigrant SMEs, as highlighted in the previous paragraph, a very pertinent unanswered question is as follows: '[ $w]$ hy does such discrimination against immigrant SMEs exist?' The contemporary literature that explored the attitude of FFIs towards financing immigrant SMEs in South Africa is hard to find. For this reason, the aim of this research study was to explore the accessibility of financial capital from FFIs to immigrant SMEs in Johannesburg, South Africa from a supply-side perspective. From this research study, the objectives developed are as follows:

- to understand how FFIs perceive the financing of immigrant SMEs in South Africa

- to explore the requirements that impact the willingness of FFIs to finance immigrant SMEs in South Africa

- to identify the challenges faced by FFIs in financing immigrant SMEs in South Africa.

\section{Theories and literature review}

TheNeoclassical economic theory of migration conceptualised immigrants as citizens that migrate from their country of origin to pursue opportunities and wealth in another country (Massey et al. 1993). From this conceptualisation offered by Massey et al. (1993), it is understood that immigrant SMEs in South Africa are those businesses owned and managed by immigrants (non-South African citizens). A research study by Ngota, Mangunyi and Rajkaran (2017) highlighted that most immigrant SMEs in South Africa are owned and managed by citizens from Cameroon, Democratic Republic of Congo, Ethiopia, Ghana, Nigeria, Somalia, China and Zimbabwe with high risk and innovative mindset. However, Ngota et al. (2017) noted that immigrant SMEs struggle to access credit from FFIs in South Africa despite their tolerance to high risk and innovative mindset. Bushe (2019:214) asserted that the success of immigrant SMEs compared with local SMEs in South Africa is largely attributed to their innovative mindset.

Furthermore, Schumpeter's (1934) Entrepreneurship Theory of Innovation (ETI) identified innovation as the main driver of reimagining business. This theory advocates that innovative businesses are capable of accessing strategic resources (e.g. financial capital), identifying novel opportunities and make timely strategic decisions. In addition, according to the resource-based view (RBV) theory by Penrose (1959), businesses can achieve a high level of performance and sustain their competitive advantage by acquiring heterogeneous resources that are difficult to create (financial capital), to substitute (innovativeness) and to imitate (strategy). Common to both the ETI and RBV theories, the internal environment in a business contributes towards the growth and success of such a business. Therefore, businesses with resources and superior internal capabilities 
are more likely to achieve a competitive advantage that is sustainable and ultimately, result in a better financial performance as supported by Asah, Louw and Williams (2020), and Radipere and Dhliwayo (2014). However, both studies (Asah et al. 2020; Radipere \& Dhliwayo 2014) acknowledge the impact of information asymmetry (when capital providers such as FFIs have less information on the financial circumstances and prospects of a business than owners or managers). According to information asymmetry theory (IAT) by Stiglitz and Weiss (1981), information asymmetry can impact the willingness of FFIs to finance immigrant SMEs.

Arguments put forward by Arena (2011:394) and La Rocca, La Rocca and Cariola (2011:109) are that information asymmetry causes FFIs to adopt credit rationing behaviour as postulated by the IAT. Credit rationing behaviour arises from imperfect market conditions, leading to credit rationing, lack of transparency, low levels of accountability for credits, questionable credit worthiness of SMEs, lack of credible collateral, and market risks. Moreover, La Rocca et al. (2011:110) stated that most immigrant SMEs are not sufficiently financially stable to access credit from FFIs because these SMEs cannot afford market interest rates. Makomeke, Makomeke and Chitura (2016:64), and Chowdhury and Alam (2017:56) challenged the view by La Rocca et al. (2011:111) that immigrant SMEs are not sufficiently financially stable, and therefore, FFIs are not interested in financing immigrant SMEs. Makomeke et al. (2016:66) argued that FFIs do not perceive immigrant SMEs as beneficial to them because they perceive them to be risky and are uncertain of their business performance and financing structure. For this reason, Makomeke et al. (2016:67) contend that the inadequate financing of immigrant SMEs is largely a consequence of the unfavourable credit requirements put in place by FFIs. A research study by Asah et al. (2020) also advocated that FFIs should publish all the credit requirements required from immigrant SMEs instead of indicating that a sound business plan and collateral are the only requirements that impact the willingness of FFIs to finance SMEs in South Africa.

The importance of this study is further emphasised by the GEM (2020) report that draws attention to the fact that availability of finance is a major problem for most entrepreneurs in South Africa. The report further highlights that this issue must be addressed to encourage an environment promoting entrepreneurship and SME development. In addition, Herrington and Kew (2014) highlighted a number of research gaps that must be addressed in terms of improving SMEs access to finance from FFIs in South Africa. In particular, research studies on monitoring the demand versus the supply of finance to SMEs in different sectors and different ownership types (local versus immigrant SMEs) are needed. These authors caution that treating SMEs as a uniform group, regardless of their sector and ownership type, offers limited research and practical implications.

A research study by Fatoki and Asah (2011:174) confirmed that SMEs in different sectors and with different ownership types have distinct characteristics and face different problems, obstacles and solutions for accessing financial capital from FFIs. Another study by Makomeke et al. (2016:69) pointed out that FFIs over the years find it difficult to invest in immigrant SMEs because of their experience of high volumes of non-performing credit as a result of weak credit examination, resulting in most credit applications from immigrant SMEs being rejected. The high credit rejection rate, as corroborated by SEDA (2017), has left most immigrant SME owners confronted with questions such as ' $[w]$ hat are the requirements FFIs are looking for from me and my business?' The contemporary literature (Bushe 2019:212; Chowdhury \& Alam 2017:59; Liang et al. 2017:137) indicates that FFIs have become very strict, more risk averse and more prudent in adhering to the credit requirements put in place when assessing and evaluating credit application from immigrant SMEs. Liang et al. (2017:137) concluded that FFIs' risk-averse attitude and the credit requirements used in screening credit applications are a major hindrance to SMEs.

From the insights gained from the relevant theories and literature review, it could be construed that FFIs are not willing to support development of SMEs in South Africa despite the major role played by immigrant SMEs in the South African economy in terms of employment creation, poverty reduction, equitable distribution of income and the overall stimulation of the economy (World Bank 2019). However, the response from one of the respondents in this study noted that 'as a bank one of our primary aims is to support small businesses growth from small to medium to large corporate body that is self-sustainable', which implies that FFIs are willing to support SMEs (be it local or immigrant) to gain financial independence. Given the assertion highlighted above, why do immigrant SMEs struggle to access financial capital from FFIs in South Africa? Is it because in-depth research that highlights the requirements that impact the willingness of FFIs to finance immigrant SMEs or the challenges faced by FFIs in financing immigrant SMEs in South Africa is hard to find or has not been performed to educate immigrant SME owners? Understanding the reason why finance from FFIs is not readily available will result in recommendations that will improve the availability of financial capital to immigrant SMEs. Thus, the primary aim of this study stems from the lack of accessibility of financial capital from FFIs to immigrant SMEs in South Africa. Liang et al. (2017:136) and Chowdhury and Alam (2017:58) suggested that whilst it is debatable whether SMEs in South Africa have or do not have access to credit from FFIs, such a debate does not arise for immigrant SMEs. Bushe (2019:212) proclaimed that immigrant SMEs in South Africa experience an acute shortage of finance. 


\section{Research design, approach and method}

This study used a qualitative research design located within the interpretivistic research paradigm and grounded in the epistemological tradition of constructivism in order to achieve the research objectives (Collis \& Hussey 2014). A constructivist approach advocates an objective standpoint, constructed from the individual's view and social interaction. It is based on the premise that multiple realities and interpretations exist.

This study focused on the eight largest FFIs responsible for about $91 \%$ of all assets and about $85 \%$ of all liabilities in the commercial banking sector in South Africa (Banking Association of South Africa 2019). Formal financial institutions are the ones that provide financial services to commercial and retail customers (e.g. providing debt capital to individuals and businesses). The eight FFIs employ about 106 business and credit managers in the Gauteng province. These banks are responsible for specifying all the requirements and policies guiding lending decisions of business and credit managers at a branch level. The head office banks also have more knowledge and experience in making lending decisions. The researcher used purposive sampling in selecting the participants from the eight FFIs in Gauteng, often referred to as the 'head office banks'. The purposive sampling focused on business and credit managers at a head office level, as interviewing these managers would yield more insights than interviews with branch office managers. Taking into consideration the requirements and code of practice governing credit lending in each FFI, interviewing more than one business and credit manager from a single institution would normally lead to data saturation. Therefore, a credit manager and a business manager were interviewed from each institution, giving a total of eight business managers and eight credit managers who voluntarily accepted being interviewed.

\section{Data collection}

The researcher used face-to-face in-depth interviews (conducted in English) to collect data for this study between September and December in 2019. Each interview lasted for about $45-60 \mathrm{~min}$. The interview guide was divided into four sections. The first section was the demographical characteristics of participants. The second, third and fourth sections focused, respectively, on how FFIs perceive financing immigrant SMEs, the credit requirements that impact the willingness of FFIs to finance immigrant SMEs and challenges experienced by FFIs in assessing credit applications from immigrant SMEs.

The qualitative data collected were transcribed, analysed and then stored in a disc drive by the researcher for a period of five years and deleted thereafter. In order to enhance the credibility and legitimacy of the study findings, all the quality criteria applicable to qualitative research were responded to, as will be outlined in the next section.

\section{Data analysis}

This study employed the five-step process of content analysis as outlined by Terre Blanche, Durrheim and Kelly (2006), namely, familiarisation and immersion, inducing themes, coding, elaboration and interpretation, and checking. In terms of familiarisation and immersion, the researcher gained an overview of the depth and diversity of the interviews, and identification of recurrent themes and issues, inducing themes (pertinent themes at the familiarisation phase are then examined in detail and compared to determine patterns, similarities and differences), coding (data are broken down into meaningful pieces and then group data together under different headings), elaboration (the researcher explores the themes more closely and build up a picture of the data as a whole), interpretation and checking (performed by thematic categories).

\section{Qualitative research criteria and limitations}

Reliability and validity are essential quality criteria in quantitative research. In qualitative research design, credibility, neutrality or confirmability, consistency or dependability, and applicability or transferability are essential criteria for quality. The data for this study were evaluated in terms of the qualitative quality research criteria (Collis \& Hussey 2014). Confirmability implies other researchers using the same procedures in the same setting, and would note similar contents, patterns, keywords and conclusions. Credibility of the study findings was enhanced by providing the participants with a copy of the analysed data for confirmation. Additionally, a clear description of the analysis, supported by a thorough research design and data analysis, contributed to the quality of the research findings (Collis \& Hussey 2014). With regard to transferability of the research findings, this study was limited to the head offices of the eight selected FFIs located in Gauteng. Despite the indepth insights obtained from the participants, these research findings were limited to the eight selected FFIs. Consequently, the findings are not generalisable to other FFIs operating in South Africa. Nevertheless, the findings could be useful to other FFIs, which were not part of this research study.

\section{Research findings}

Interviews were conducted with eight credit managers $\left(C_{1}-C_{8}\right)$ and eight business managers $\left(M_{1}-M_{8}\right)$. Out of the 16 participants who took part in this study, seven (44\%) were female participants - three credit managers and four business managers, whilst nine (56\%) were male participants - five credit managers and four business managers. Additionally, 12 (75\%) of the participants had at least a Bachelor's degree, nine (56.25\%) were aged between 35 and 40 years, and 13 (81.25\%) participants had more than 10 years of banking experience. The research findings, aligned with addressing the research goals stated above, are presented in the following sections. 


\section{How formal financial institutions perceive financing immigrant small and medium enterprises}

Of the eight FFIs this study focused on, five do not provide any form of business credit to immigrant SME owners without a South African permanent resident permit (SAPRP) with a South African ID. The participants from these five FFIs observed that they do not finance immigrant SMEs without an SAPRP with a South African ID as part of institutional policy, as captured in this excerpt from participant $\mathrm{M}_{4}$ :

'We do not give business credit to businesses owned by a foreign national or businesses that a foreigner without a SAPRP is a coowner because the risk is too high. I can tell you right now that all the business credit applications that have come to our office this year was rejected simply because a co-owner of the business is a foreigner using a passport with business permit or work permit.' (Participant $\mathrm{M}_{4}$, Male, Age range 50-55, duration of current position: 11 years)

Regarding the other three FFIs that provide business credit to immigrant SME owners without SAPRPs but who possess either a business permit or work permit, the lending terms are not the same, as explained by participant $C_{2}$ :

'There are two categories of immigrants according to our business credit model. Those with SAPRP with South African ID we consider them same as locals because it is easier for us to verify their credit history. While those with business or work permit fall in another category and this is the category with the most risk because it is difficult for us to verify their credit history and the credit terms for such clients are different. Overall, I can say we are happy to finance those that agree to our credit terms and do qualify for business credit.' (Participant $\mathrm{C}_{2}$, Female, Age range $30-34$, duration of current position: 3 years)

This finding is consistent with that of Radipere and Dhliwayo (2014) and Tengeh and Nkem (2017) that FFIs are uninterested in financing immigrant SMEs and that this is at the root of the discrimination hypothesis. For FFIs that finance immigrant owned SMEs without SAPRP, one of the participants $\left(C_{1}\right)$ commented that:

'We are very committed to supporting all businesses because they are important to us and we are aware of the risk of financing small businesses owned by foreign nationals. However, before we approve a business credit to a foreign national who owns a business in South Africa, that person must have had his business account with us for at least three years. That way we know the clients, the financials of the business and he must also provide a first-class collateral that is valued at twice the loan value, and his business or work permit must be valid for the duration of the loan.' (Participant $C_{1}$, Male, Age range 35-40, duration of current position: 5 years)

In addition, participant $\mathrm{M}_{3}$ highlighted:

'In order to reduce the lending risk when we lend to foreign nationals, the amount of the loan must not exceed $70 \%$ of the value of the pledged collateral. Meaning that, if the amount the person is looking for is more than $70 \%$ of the value of the pledged collateral, for a good business, we will reduce the amount of the loan to equal $70 \%$ of the collateral. Otherwise, we will reject the loan application.' (Participant $\mathrm{M}_{3^{\prime}}$ Female, Age range 30-34, duration of current position: 5 years)

\section{Requirements that impact the willingness of formal financial institutions to finance immigrant small and medium enterprises}

As shown in Table 1 perspectives of participants on the requirements that affect the willingness of FFIs to finance immigrant SMEs are provided. In Table 1, the code and number of participants is indicated in the left column; the particular requirement is in the next column and the frequency of citations is given in the right column. This means that, for example, in terms of collateral, whilst all the participants regarded this factor as being important, the importance was further enhanced by the frequency $(n=32)$ of its mention by the participants. The level of importance of each factor was, therefore, determined by the frequency of mention rather than by the number of participants.

As revealed in Table 1, collateral $(n=32)$, equity contribution $(n=32)$ and an SAPRP with South African ID $(n=32)$ are the imperative criteria considered by FFIs that significantly impact their willingness to provide business credit to immigrant SMEs. The ability and willingness of immigrant SME owners with SAPRPs and South African IDs to pledge collateral and contribute personal finance (equity contribution) signal the commitment and confidence of the owners about the prospect of the success of the business. The participants explained that FFIs usually consider collateral in the form of an investment account, fixed assets such as buildings, surety and contract agreements. Participant $\mathrm{C}_{1}$ pointed out that:

TABLE 1: Perspectives of participants on the requirements that have an impact on the willingness of formal financial institutions to finance immigrant small and medium enterprises.

\begin{tabular}{|c|c|c|}
\hline Participants & $\begin{array}{l}\text { Requirements affecting } \\
\text { willingness of FFls to grant } \\
\text { credit }\end{array}$ & $\begin{array}{l}\text { Frequency } \\
\qquad(n)\end{array}$ \\
\hline $\begin{array}{l}C_{1} ; C_{2} ; C_{3} ; C_{4} ; C_{5} ; C_{6} ; C_{7} ; C_{8} ; M_{1} ; M_{2} ; M_{3} ; M_{4} ; \\
M_{5} ; M_{6} ; M_{7} ; M_{8} .\end{array}$ & Collateral & 32 \\
\hline $\begin{array}{l}C_{1} ; C_{2} ; C_{3} ; C_{4} ; C_{5} ; C_{6} ; C_{7} ; C_{8} ; M_{1} ; M_{2} ; M_{3} ; M_{4} ; \\
M_{5} ; M_{6} ; M_{7} ; M_{8}\end{array}$ & Equity contribution & 32 \\
\hline $\begin{array}{l}C_{1} ; C_{2} ; C_{3} ; C_{4} ; C_{5} ; C_{6} ; C_{7} ; C_{8} ; M_{1} ; M_{2} ; M_{3} ; M_{4} ; \\
M_{5} ; M_{7} ; M_{8}\end{array}$ & $\begin{array}{l}\text { SAPRP with South African } \\
\text { ID }\end{array}$ & 32 \\
\hline $\mathrm{C}_{1} ; \mathrm{C}_{2} ; \mathrm{C}_{4} ; \mathrm{C}_{5} ; \mathrm{C}_{7} ; \mathrm{C}_{8} ; \mathrm{M}_{1} ; \mathrm{M}_{2} ; \mathrm{M}_{4} ; \mathrm{M}_{5} ; \mathrm{M}_{7} ; \mathrm{M}_{8}$ & $\begin{array}{l}\text { Audited financial } \\
\text { statements }\end{array}$ & 28 \\
\hline$C_{1} ; C_{2} ; C_{4} ; C_{5} ; C_{7} ; C_{8} ; M_{1} ; M_{2} ; M_{4} ; M_{5} ; M_{7} ; M_{8}$ & $\begin{array}{l}\text { Credit profile of business or } \\
\text { owner }\end{array}$ & 24 \\
\hline$C_{1} ; C_{2} ; C_{3} ; C_{5} ; C_{7} ; C_{8} ; M_{1} ; M_{2} ; M_{4} ; M_{5} ; M_{7} ; M_{8}$ & Annual business turnover & 24 \\
\hline$C_{1} ; C_{2} ; C_{4} ; C_{5} ; C_{7} ; C_{8} ; M_{1} ; M_{2} ; M_{4} ; M_{5} ; M_{7} ; M_{8}$ & $\begin{array}{l}\text { Valid business or work } \\
\text { permit }\end{array}$ & 20 \\
\hline$C_{1} ; C_{2} ; C_{3} ; C_{6} ; C_{7} ; C_{8} ; M_{1 ;} M_{2 ;} M_{3 ;} M_{6} ; M_{7} ; M_{8}$ & $\begin{array}{l}\text { Business registration } \\
\text { documents }\end{array}$ & 18 \\
\hline$C_{1} ; C_{2} ; C_{3} ; C_{5} ; C_{6} ; M_{1} ; M_{2} ; M_{3} ; M_{5} ; M_{8}$ & Entrepreneurial orientation & 16 \\
\hline$C_{1} ; C_{2} ; C_{4} ; C_{5} ; M_{1} ; M_{2} ; M_{3} ; M_{5} ; M_{8}$ & $\begin{array}{l}\text { Comprehensive business } \\
\text { plan }\end{array}$ & 13 \\
\hline$C_{1} ; C_{2} ; C_{3} ; C_{4} ; C_{6} ; M_{1} ; M_{2} ; M_{3} ; M_{5} ; M_{8}$ & $\begin{array}{l}\text { Completed credit } \\
\text { application form }\end{array}$ & 12 \\
\hline$C_{1} ; C_{2} ; C_{3} ; C_{5} ; C_{6} ; M_{1} ; M_{2}$ & Quotation from suppliers & 10 \\
\hline $\mathrm{C}_{2} ; \mathrm{C}_{5} ; \mathrm{C}_{6} ; \mathrm{M}_{2} ; \mathrm{M}_{3} ; \mathrm{M}_{5}$ & Relationship with the bank & 4 \\
\hline
\end{tabular}

Note: $C_{1}-C_{8}$ are all Credit Managers; $M_{1}-M_{8}$ are all Business Managers.

FFIs, formal financial institutions; SAPRP, South African permanent resident permit; ID, identity document. 
'In order for us to reduce the risk of lending to foreign nationals, all business credit applications must be reinforced with a firstclass collateral that must have been assessed and approved by our team of evaluators. As I explained to you earlier, the value of the collateral must be twice the loan amount requested by the applicant. However, in the case of an investment account with us, the investment account will be blocked and cannot be cashed by the owner until the loan is fully paid off.' (Participant $C_{1^{\prime}}$ Male, Age range 35-40, duration of current position: 5 years)

Worthy of mention is the fact that FFIs do not accept investment policies from immigrant SME owners because of certain clauses in the policy. Conversely, those immigrant SME owners who hold an SAPRP with a South African ID $(n=32)$ and are willing to contribute personal finance to the equity of the business $(n=32)$ signal to the FFI that the owner is investment-ready, and this will help boost the acceptability of the credit application, as participant $\mathrm{C}_{4}$ explained:

'Well as I told you before, it is very easy for us to verify personal as well as business information of foreign nationals with South African ID. Moreover, I feel good and interested when a foreign national with a South African ID invests his or her personal money in the business because this tells you that the owner is very serious about the business. I can say most of the business credit we have approved in the past and try to monitor how the foreign nationals manage the credit has always yield us positive result.' (Participant $C_{4^{\prime}}$ Male, Age range 35-40, duration of current position: 6 years)

Having audited financial statements $(n=28)$ is the fourth most important requirement that influences the willingness of FFIs to finance immigrant SMEs because it reveals the financial performance of the business. This is used by FFIs to evaluate the creditworthiness of the owner and the business. Participant $\mathrm{M}_{1}$ stated the following:

'We usually ask for 3 years audited financial statement of the business. This is very important because we use the financials to evaluate the amount of profit the business is making monthly, the amount of credit the business is worth and if the business will be able to repay the credit from the profit the business is generating monthly.' (Participant $\mathrm{M}_{1}$, Female, Age range 35-40, duration of current position: 7 years)

The credit profile of the business and its owner $(n=24)$ provides information about the credit history of the business and the owners. Such information is used by FFIs to determine the kind of client they are dealing with, as noted by participant $\mathrm{M}_{4}$ :

'The credit profile of the business and its owners help us determine if the client is a level one or level two or level three client. Level one are clients seeking credit for the first time and are the most risky. Level two are clients that have taken credit in the past but not more than four times and this level is considered the moderate risk level clients. Level three are clients who have taken credit more than four times in the past and their credit score is very high. Level three are the least risk clients.' (Participant $\mathrm{M}_{4^{\prime}}$ Male, Age range 50-55, duration of current position: 11 years)

Annual business turnover $(n=24)$, just like the audited financial statements explained above, is used to assess the performance of the business and evaluate the creditworthiness of the business. A valid business or work permit $(n=20)$ helps FFIs to know the duration the credit can be spread and paid off before the expiration of the permit, as explained by participant $\mathrm{C}_{1}$ above. Business registration documents $(n=18)$ are also very important as FFIs only finance immigrant businesses in the formal sector registered with the Department of Trade and Industry agencies, such as SEDA. Entrepreneurial orientation of immigrant SME owners is very important to FFIs as it helps them to assess the risk behaviour and competitiveness of the owner. Participant $\mathrm{M}_{3}$ stated the following:

'Since I started working as a business manager here, I can tell you that foreign nationals are very hard-working and competitive, but they like to take a lot of risk in their business. Their risky behaviour makes us very reluctant to give them credit since we do not have time to monitor how they use the credit. So, their entrepreneurial orientation is really concerning as we are trying to avoid risky investment and losing money in the form of bad debts.' (Participant $\mathrm{M}_{3^{\prime}}$ Female, Age range 30-34, duration of current position: 5 years)

A comprehensive business plan $(n=13)$ will provide insights into the ability of SME owners to articulate a good business plan that meets the requirements of investors, such as FFIs. For applicants who do not have an account with the FFI they seek business credit from, a credit application form is provided by all FFIs that applicants must complete. A correctly completed credit application form $(n=12)$ provides vital information to the participants to help them evaluate and make quick decisions on any credit application, as described by participant $\mathrm{M}_{8}$ :

'All clients applying for a business or home loan, who do not have an account with us must complete the credit application form. However, if you have an account with us, you do not have to complete the credit application form as we already have all your vital information we will need when you opened an account with us.' (Participant $\mathrm{M}_{8}$, Male, Age range 35-40, duration of current position: 4 years)

For immigrant SME owners who want to purchase business asset(s), FFIs ask for at least two quotations from suppliers $(n=10)$, as captured in this excerpt from participant $C_{2}$ :

'I usually ask my clients to bring at least two quotations from different suppliers for me to confirm the value of the credit the client has applied for. I too will also contact suppliers that we have on our database who can supply similar goods to confirm the price. If our supplier can supply at a reasonable price, we will prefer to use our supplier.' (Participant $\mathrm{C}_{2}$, Female, Age range 30-34, duration of current position: 3 years)

Relationship with the bank $(n=4)$ is the least important requirement for FFIs when considering financing immigrant SMEs. Participant $\mathrm{C}_{6}$ noted the following:

'I know some clients at a personal level and their businesses. So, if such client applies for a business loan, I might be able to put in a good motivation as to why the credit application should be considered.' (Participant $C_{6}$, Male, Age range 41-45, duration of current position: 4 years) 
TABLE 2: Perspectives of participants on the challenges faced by formal financial institutions when considering financing immigrant small and medium enterprises.

\begin{tabular}{llc}
\hline Participants & $\begin{array}{l}\text { Participants' perspectives } \\
\text { on the challenges faced by } \\
\text { FFls }\end{array}$ & $\begin{array}{c}\text { Frequency } \\
\text { (n) }\end{array}$ \\
\hline$C_{1} ; C_{2} ; C_{3} ; C_{4} ; C_{5} ; C_{6} ; C_{7} ; C_{8} ; M_{1} ; M_{2} ; M_{3} ; M_{4} ;$ & Lack of SAPRP & 28 \\
$M_{5} ; M_{6} ; M_{7} ; M_{8 .}$ & 24 \\
$C_{1} ; C_{2} ; C_{3} ; C_{4} ; C_{5} ; C_{6} ; C_{7} ; C_{8} ; M_{1} ; M_{2} ; M_{3} ; M_{4} ;$ & Lack of first-class collateral & 24 \\
$M_{5} ; M_{7}$. & Insufficient financial capital & 16 \\
$C_{3} ; C_{5} ; C_{6} ; C_{7} ; C_{8} ; M_{4} ; M_{5} ; M_{6} ; M_{7} ; M_{8 .}$ & Poor financial records & 12 \\
$C_{1} ; C_{2} ; C_{4} ; C_{5} ; M_{1} ; M_{2} ; M_{3} ; M_{5} ; M_{6 .}$ & Poor credit history & 8 \\
$C_{1} ; C_{4} ; C_{6} ; C_{7} M_{4} ; M_{6 .}$.
\end{tabular}

FFIs, formal financial institutions; SAPRP, South African permanent resident permit.

\section{Challenges faced by formal financial institutions when considering financing immigrant small and medium enterprises}

The views of the participants on the challenges faced by FFIs in financing immigrants SMEs are summarised in Table 2. The information in Table 2 will be interpreted similarly to the explanation provided for Table 1.

Lack of SAPRP $(n=28)$ is the most serious challenge faced by FFIs when considering financing immigrant SMEs. The fact that some immigrant SME owners do not have an SAPRP with a South African ID makes it very challenging for FFIs to consider financing them because FFIs find it difficult to monitor all the business transactions of immigrants, as explained by participant $\mathrm{C}_{3}$ :

'We have realised that the passport number and sometimes the names of immigrants changes each time they renew their passport and this makes it difficult for us to keep track of them. But it is easier for us to track all business transactions for immigrants with SAPRP with South African ID anywhere in South Africa and this helps to reduce the lending risk.' (Participant $\mathrm{C}_{3}$, Male, Age range 41-45, duration of current position: 7 years)

Lack of first-class collateral $(n=24)$ is the next most serious challenge faced by FFIs when considering financing immigrant SMEs. The contemporary literature emphasises that the use of collateral has become a very prominent feature of credit contracts between immigrant SMEs and lenders such as FFIs. The risk of financing and problems related to the cost of supervising immigrant SMEs' behaviour can be mitigated using collateral. This is what participant $C_{2}$ had to say on the matter:

'First class collateral in the form of investment account, personal business assets or insurance schemes is what we prefer as security, and the value of the collateral must be twice the value of the credit. Unfortunately, most of the collateral foreign nationals present does not meet our criteria. For example, most foreign nationals offer their residential home as collateral. For such an asset to qualify as a first-class collateral, the property must be insured and the owner must have a life assurance, otherwise the property is useless.' (Participant $\mathrm{C}_{2}$, Female, Age range 30-34, duration of current position: 3 years)

It could be construed from this participant's opinion that immigrant SMEs would find it extremely challenging to access finance from FFIs without collateral. Conversely, insufficient financial capital $(n=16)$ is the second most serious challenge faced by FFIs when considering financing immigrant SMEs. As the contemporary literature asserts, most FFIs are uninterested in financing immigrant SMEs because of the high risk involved, as participant $\mathrm{M}_{4}$ stated:

'So, with an immigrant in South Africa who has a passport with a stamped permit operating a business, you have to prove that you have brought in two-million-rand capital and you must have an account with us. Now, some immigrants who had such money have invested it in the business and they want more. The fact that we do not have any information about their credit history and most of them are level one credit clients makes it difficult for us to finance them because the risk is too high.' (Participant $\mathrm{M}_{4}$, Male, Age range 50-55, duration of current position: 11 years)

Poor financial records ( $n=12)$ of immigrant SMEs is another serious challenge faced by FFIs contemplating financing immigrant SMEs. Formal financial institutions use the financials to evaluate the present and forecast the future performance of the business. Participant $\mathrm{M}_{6}$ observed the following:

'The financials of the business is a very important document to us, and it is one of the challenges most small businesses face. It is the reason why we want their management account opened with us for at least three years so that we know the performance of the business.' (Participant $\mathrm{M}_{6}$ Female, Age range 41-45, duration of current position: 8 years)

'The absence of sufficient information about borrowers, especially immigrant SMEs and their poor credit history $(n=$ 8), makes it difficult for FFIs to assess the creditworthiness of the business and its owners. The credit history record of diligent payments is an important aspect of a successful credit application, as explained by participant $C_{7}$ :

'As I explained to you before, it is the same for foreign nations. Assume you have been in business for 5 years; we would look at your personal credit record and your business credit record. Obviously, after 5 years, you would have a credit record. We would then evaluate if you will be able to pay your credit on time or if your business in the past failed to pay its credit on time. We usually check the credit record of the owners to know if they have not failed to pay their debt in the past.' (Participant $C_{7}$, Female, Age range 35-40, duration of current position: 6 years)

\section{Discussion}

The research findings presented in section 'How FFIs perceive financing immigrant SMEs' indicate that FFIs perceive immigrant businesses as not only beneficial to their business but also very risky. According to the participants, the risk perception in financing immigrant SMEs seems to be greater than the perception of the benefits. In other words, should the risk of any credit application not be tolerable based on the institution's risk credit model, the credit application is most probably rejected or the applicant is requested to revise the credit application. Accordingly, the lending terms when considering lending to immigrant SMEs are different from those of local SMEs. The difference in 
lending terms also reflects the very high credit rejection rate by FFIs, indicating the low availability of business credit to immigrant SMEs. This finding is consistent with that of Stiglitz and Weiss (1981) who developed the theoretical contributions on credit rationing, given that FFIs always want to mitigate the risk of granting credit to immigrant SMEs. Another research study by Weber (2018) acknowledged that FFIs are not interested in lending to certain businesses because of the high-risk profile of the business and its owners.

As noted in section 'Requirements that impact the willingness of FFIs to finance immigrant SMEs', pledged collateral, equity contribution, and possession of an SAPRP and South African ID were the most important requirements that impact the willingness of FFIs to finance immigrant SMEs. Lack of valuable (first class) collateral, such as tangible assets and equity contribution, is the most important reason why credit from FFIs is not available to immigrant SMEs. According to GEM (2020), immigrant SME owners must start saving for collateral if they expect to access credit from FFIs, given the turbulent economic environment. It is this environment, coupled with the COVID-19 pandemic, which is forcing FFIs to be more risk averse when it comes to lending to immigrant SMEs. Osano and Languitone (2016:5) argued that collateral helps to mitigate informational asymmetries, moral hazard and credit extension problems that arise between FFIs and immigrant SMEs. Formal financial institutions generally do not finance businesses without an equity contribution and tangible collateral. Therefore, in order to improve the availability of credit, immigrant SMEs need to prove that they are investment-ready by planning and saving to have some equity contribution available. Providing collateral and an equity contribution signals confidence of immigrant SMEs about the likelihood of business success, and align the interests of the borrower with those of the lender (World Bank 2019). The possession of an SAPRP by foreign nationals is a signal that they are willing to settle, operate legitimate businesses and adhere to the trade policies of South Africa. This will help to boost the confidence and trust level of FFIs, thus enabling them to track all business and credit transactions of immigrant SMEs, as argued by D'Aurizio, Oliveiro and Romano (2015:281).

Audited financial statements, the credit profile of the owner or business and annual business turnover reports are used by FFIs to evaluate the creditworthiness of the owner and the business, and forecast the business's present and future performance (Ntiamoah, Li \& Kwamega 2016:562). The possession of a valid business or work permit and business registration documents signals the legality and legitimacy of the owner and the business. With respect to the five dimensions of entrepreneurial orientation (innovation, competitive, autonomy, aggressiveness, proactivity and risktaking), FFIs are most concerned about the risk-taking behaviour of immigrant SME owners. Although the contemporary literature applauds the innovative, competitive, aggressive and proactive behaviour and contributions of immigrant SMEs to economic growth (Furawo \& Scheepers 2018:35; Jenkins \& McKelvie 2016:176), the current economic climate throttled by the pandemic has forced FFIs to ignore the other dimensions of entrepreneurial orientation and focus on the risk behaviour of immigrant SMEs. As such, FFIs have developed more risk-averse behaviour, limiting the availability of credit to immigrant SMEs.

A comprehensive business plan provides both the business and FFIs with financial information to assess the enterprise's strategies and model, and to determine the viability and growth prospect of the enterprise. However, a completed credit application form provided by FFIs evaluates whether the credit application meets the minimum credit requirements, whilst FFIs also use quotations from suppliers to confirm the value of the asset(s) and decide on which supplier to purchase from. Furthermore, if an immigrant SME has a close and long-standing relationship with a bank and has not defaulted with credit payments, it will access credit more easily than those without such a relationship. Arruda, Girao and Lucena (2015:319) advised that having a debtor and creditor relationship is useful in reducing information asymmetry.

In terms of the findings in section Challenges faced by FFIs when considering financing immigrant SMEs, GEM (2020) posited that most immigrant entrepreneurs find it difficult to access credit from FFIs in South Africa because they do not hold an SAPRP with South African ID. Consequently, FFIs are not willing to take much risk in financing immigrant SMEs because they fear that the immigrant SME might default with payment owing to the high interest rate. As noted by one of the participants $\left(\mathrm{C}_{2}\right)$, 'the interest rate for business credit for foreign nationals is slightly different from local SMEs'. As a result, FFIs have resorted to holding first-class collateral as a means to reduce the lending risk, given that collateral can be repossessed by the creditor in case of default, consequently enhancing creditor protection (Rahman, Zheng \& Ashraf 2015:96). Whilst collateral might be held as security, the contemporary literature (Baby \& Joseph 2016:3; GEM 2020) nonetheless suggests that financing immigrant SMEs with little or no equity contribution from the owners is riskier than financing large corporations. Besides, the poor financial records and poor credit history of immigrant SMEs tend to compound the issue of financing because FFIs find it challenging to judge the creditworthiness and performance of immigrant SMEs (Ntiamoah et al. 2016:562).

\section{Conclusion and managerial implications}

Despite the risk-averse lending behaviour of FFIs, they consider immigrant SMEs as beneficial to their business, although very risky. Formal financial institutions are only willing to finance those immigrant SMEs who can provide first-class collateral worth more than the credit sought and who can contribute significantly to the equity of the business. It is clear that FFIs always want to mitigate the risk of financing immigrant SMEs. The findings further revealed that certain requirements impact the willingness of FFIs to 
finance immigrants SMEs. Based on the findings, the following recommendations with the aim of enhancing the financing of immigrant SMEs are made.

Training and communication regarding the requirements of FFIs for financing can help immigrant SME owners to get investment ready. Formal financial institutions can create awareness of their financing requirements through advertisements and communication with immigrant SME trade associations. There is also a need for immigrant SME owners to invest in personal business properties, and to plan and save to secure some equity contribution, given that it would be impossible to get finance from FFIs without collateral and an equity contribution. Additionally, immigrant SME owners need to take responsibility for their own learning and personal development through training and workshops, especially in the areas of business and financial management skills, to help them understand how to maintain proper business records. Proper business records will help immigrant SME owners to articulate a good business plan and provide an avenue for them to assess the financial performance of their business in real time in order to know whether the business is doing well.

It is paradoxical that FFIs most often consider financing immigrant SMEs that must have been indebted and capable of paying their debt than those without a credit record, and are charged a high interest rate. Instead, FFIs should consider financing more Level 1 credit applicants (applicants without debt) as they are debt free. According to Pecking order theory, enterprises should only seek external capital such as debt finance, provided they cannot raise additional capital from existing shareholders (internal equity) or retained earnings is not sufficient for growth. Thus, it can be argued that Level 1 credit applicants are without credit history because they did not require debt financing in the past. Additionally, FFIs should charge all credit applicants (be it Level 1 or 2 or 3 ) the same interest rate. This will help boost the chance of more Level 1 credit applicants to secure credit. As for immigrants without the SAPRP, the government needs to be flexible with the requirements to qualify for SAPRP for immigrants with businesses in South Africa, bearing in mind their tremendous importance in employment, poverty alleviation and economic growth.

Given that this study focused only on eight FFIs, the findings cannot be generalised to other FFIs. Hence, further research could focus on the lending requirements and challenges faced by the other FFIs in South Africa. Additionally, further research could be conducted on the criteria and barriers to lending by government agencies and other financial institutions involved in lending to SMEs. Further research could also be conducted in other countries to confirm whether the lending criteria and challenges are similar.

\section{Acknowledgements}

The authors wish to acknowledge Mrs. Ruth Coetzee for language editing the article.

\section{Competing interests}

The authors declare that they have no financial or personal relationships that may have inappropriately influenced them in writing this article.

\section{Authors' contributions}

Both F.T.A. and L.L. contributed equally to the writing of this article.

\section{Ethical considerations}

Approval to conduct the study was obtained from the Department of Management Ethics Sub-Committee at Rhodes University on 21 June 2018, reference number: 2018 Man 01.03. Each participant signed a consent form. No confidential information was requested. The participants were guaranteed anonymity, confidentiality and the possibility to withdraw from participating at any time.

\section{Funding information}

The authors received no financial support for the research, authorship and/or publication of this article.

\section{Data availability}

The data that support the findings of this study are available from the corresponding author, F.T.A., upon reasonable request.

\section{Disclaimer}

The views and opinions expressed in this article are those of the authors and do not necessarily reflect the official policy or position of any affiliated agency of the authors.

\section{References}

Acs, Z.J., Estrin, S., Mickiewicz, T. \& Szerb, L., 2018, 'Entrepreneurship, institutional economics, and economic growth: An ecosystem perspective', Small Business Economics 51(2), 501-514. https://doi.org/10.1007/s11187-018-0013-9

Akinboade, O.A., 2015, 'Determinants of SMEs growth and performance in Cameroon's central and littoral provinces' manufacturing and retail sectors', African Journal of Economic and Management Studies 6(2), 183-196. https://doi. org/10.1108/AJEMS-03-2013-0033

Andersson, M. \& Waldenstrom, D., 2017, 'Hernando de Soto: Recipient of the 2017 global award for entrepreneurship research', Small Business Economics 49(4), 721-728. https://doi.org/10.1007/s11187-017-9948-5

Arena, M.P., 2011, 'The corporate choice between public debt, bank loans, traditional private debt placements, and a debt issues', Review of Quantitative Finance and Accounting 36(3), 391-416. https://doi.org/10.1007/s11156-010-0182-3

Arruda, M.P., Girao, L.F.A.P. \& Lucena, W.G.L., 2015, 'Information asymmetry and share prices: Analysis of the use of social networks in the Brazilian and U.S. capital markets', Research on Contemporary Finance 26(69), 317-330. https://doi. org/10.1590/1808-057×201501540

Asah, F.T., Louw, L. \& Williams, J., 2020, 'The availability of credit from the formal financial sector to small and medium enterprises in South Africa', Journal of Economics and Financial Science 13(1), a510. https://doi.org/10.4102/jef. v13i1.510

Baby, A. \& Joseph, C.A.C., 2016, 'Bank finance challenges faced by UAE SME sector', Arabian Journal of Business Management Review 1(5), 1-3.

Banking Association of South Africa, 2019, Our industry, viewed 10 November 2019, from www.banking.org.za/our_industry/member_banks/member_banks.aspx.

Bushe, B., 2019, 'The causes and impact of business failure among small to micro and medium enterprises in South Africa', Africa's Public Service Delivery and Performance Review 7(1), a210. https://doi.org/10.4102/apsdpr.v7i1.210

Centre for Entrepreneurs and Duedil, 2014, Migrant entrepreneurs, viewed 02 May 2020, from http://www.creatingourjobs.org/data/MigrantEntrepreneursWEB.pdf. 
Chowdhury, M. \& Alam, Z., 2017, 'Factors affecting access to finance of SMEs in Bangladesh', USV Annals of Economics and Public Administration 2(26), 55-68.

Collis, J. \& Hussey, R., 2014, 'Business research: A practical guide for undergraduate and postgraduate students', 4th edn., Palgrave Macmillan, Basingstoke.

D’Aurizio, L., Oliveiro, T. \& Romano, L., 2015, 'Family firms, soft information and bank lending in a financial crisis', Journal of Corporate Finance 1(33), 279-292. https:// doi.org/10.1016/j.jcorpfin.2015.01.002

European Commission SMEs Performance Review, 2013, Annual reports on European SMEs, viewed 03 June 2020, from http://ec.europa.eu/enterprise/policies/sme/ facts-figures-analysis/performance-review/files/supporting-documents/2013/ annual-report-smes.

Fatoki, O., 2014, 'The financing preferences of immigrant small business owners in South Africa', Mediterranean Journal of Social Sciences 5(20), 184-189. https:// doi.org/10.5901/mjss.2014.v5n20p184

Fatoki, O. \& Asah, F., 2011, 'The impact of firm and entrepreneurial characteristics on access to debt finance by SMEs in King Williams' Town, South Africa', International
Journal of Business and Management 6(8), 170-179. https://doi.org/10.5539/ Journal of Busines

Furawo, T. \& Scheepers, C.A., 2018, 'Factors impacting innovative capability of SME in Cape Town', Journal of Management and Administration 2(2), 31-59.

Global Entrepreneurship Monitor (GEM), 2020, GEM global report, viewed 19 January 2019, from https://www.gemconsortium.org/file/open?fileld=50443.

Herrington, M. \& Kew, J., 2014, GEM South Africa 2013 report, viewed 01 December 2019, from www.gemconsortium.org/docs/3336/gemsouth-africa-2013.

Jenkins, A. \& McKelvie, A., 2016, 'What is entrepreneurial failure? Implications for future research', International Small Business Journal 34(2), 176-188. https://doi. org/10.1177/0266242615574011

La Rocca, M., La Rocca, T. \& Cariola, A., 2011, 'Capital structure decisions during a firm's life cycle', Small Business Economics 37(1), 107-130. https://doi. org/10.1007/s11187-009-9229-z

Liang, L.W., Huang, Y., Liao, C.F. \& Gao, Y.T., 2017, 'The impact of SMEs' lending and credit guarantee on bank efficiency in South Korea', Review of Development Finance 7(3), 134-141. https://doi.org/10.1016/j.rdf.2017.04.003

Makomeke, P.C., Makomeke, C. \& Chitura, M., 2016, 'The effectiveness of commercial banks' credit appraisal techniques in improving Asset Quality', Journal of Economics and Finance 7(5), 63-78. https://doi.org/10.9790/5933-0705016378

Massey, D.S., Arango, J., Hugo, G., Kouaquci, A. \& Pellegrino A., 1993, 'Theories in international migration: A review and appraisal', Population and Development Review 19(3), 431-466. https://doi.org/10.2307/2938462

Ngota, B.L., Mangunyi, E.E. \& Rajkaran, S., 2017, 'Factors impeding African immigran entrepreneurs' progression in selected small and medium enterprises: Evidence from local municipality in South Africa', South African Journal of Business Management 49(1), a10. https://doi.org/10.4102/sajbm.v49i1.10
Ntiamoah, E.B., Li, D.M. \& Kwamega, M., 2016, 'Impact of government and other institutions' support on performance of small and medium enterprises in the agribusiness sector in Ghana', American Journal of Industrial and Business agribusiness sector in Ghana', American Journal of Industrial and Busi
Management 6(12), 558-567. https://doi.org/10.4236/ajibm.2016.65052

Organisation of Economic Cooperation and Development (OECD), 2017, African Economic Outlook 2017: Regional development and spatial inclusion, OECD Publishing, Paris, viewed 14 November 2019, from www.oecd.org/eco/ surveys/2017-OECD-Economic-Survey-South-Africa-overview-2017.pdf.

Osano, H.M. \& Languitone, H., 2016, 'Factors influencing access to finance by SMEs in Mozambique: Case of SMEs in Maputo central business district', Journal of Innovation and Entrepreneurship 5(13), 1-16. https://doi.org/10.1186/s13731-016-0041-0

Penrose, E., 1959, The theory of the growth of the firm, Basil Blackwell, Oxford.

Radipere, S. \& Dhliwayo, S., 2014, 'An analysis of local and immigrant entrepreneurs in South Africa's SME sector', Mediterranean Journal of Social Sciences 5(9), 189-198.

Rahman, M.M., Zheng, C. \& Ashraf, B.N., 2015, 'Bank size, risk-taking and capital regulation in Bangladesh', Eurasian Journal of Business and Economics 8(15), 95-114. https://doi.org/10.17015/ejbe.2015.015.05

Schumpeter, J., 1934, The theory of economic development, Harvard University Press, Cambridge, MA.

Small Enterprise Development Agency (SEDA), 2017, The small, medium and micro enterprise sector of South Africa, viewed 20 October 2020, from http://www.seda. org.za/Publications.

Statistics South Africa, 2020, Quarterly labour force survey, viewed 09 November 2020, from www.statssa.gov.za/? $\mathrm{p}=12948$.

Stiglitz, J.E. \& Weiss, A., 1981, 'Credit rationing in markets with imperfect information', American Economic Review 71(3), 393-410.

Tengeh, R.K. \& Nkem, L., 2017, 'Sustaining immigrant entrepreneurship in South Africa: The role of informal financial associations', Sustainability 9(8), 1396. https://doi.org/10.3390/su9081396

Terre Blanche, M., Durrheim, K. \& Kelly, K., 2006, 'First steps in qualitative data analysis', in M. Terre Blanche, K. Durrheim \& D. Painter (eds.), Research in practice. Applied methods for the social sciences, pp. 321-344, University of Cape Town Press, Cape Town.

Turyakira, P.K., 2018, 'Ethical practices of small and medium-sized enterprises in developing countries: Literature analysis', South African Journal of Economic and Management Sciences 21(1), 1-13. https://doi.org/10.4102/sajems.v21i1.1756

Weber, C.S., 2018, 'Central bank transparency and inflation (volatility) - New evidence', International Economic Policy 15(7), 21-67. https://doi.org/10.1007/ s10368-016-0365-z

World Bank, 2019, Jobs and development, viewed 18 March 2020, from www. worldbank.org/en/topic/jobsanddevelopment/overview. 